\title{
15. The Urgenda case in the Netherlands: creating a revolution through the courts
}

\author{
Marjan Minnesma
}

\section{PROMISES, PROMISES, PROMISES}

Large parts of the Netherlands are situated below sea level. ${ }^{1}$ Rising sea levels may thus become an existential threat to this country fronting the North Sea. And this threat may develop much more rapidly and with much greater severity than for other European countries. The Netherlands was a front runner on environmental policies in the 1980s and early 1990s when it belonged to the small group of countries that pushed for an international Climate Change Convention. However, somehow, the Netherlands changed from being a leader and a front runner into a laggard.

Although you could argue that countries like the Netherlands have a special responsibility to lead by example in light of their wealth, historic contribution, and per capita emissions, most such countries have dragged their feet and delayed significant action for years. The Netherlands has time and again adopted 'ambitious' future targets, only to abandon or neglect those targets a couple of years later. The result has been that, in 2018, just 7.4 percent of all energy in the Netherlands was generated by renewable sources (of which 4.5 percent was from biomass, which is not as sustainable as we once thought). ${ }^{2}$ In 2018, the Dutch $\mathrm{CO}_{2}$ emissions were nearly at the same level as they were in 1990, and there was only a slight reduction in other greenhouse gases (GHGs). ${ }^{3}$ Action to reduce emissions keeps getting pushed into the future. But as climate science shows, the lingering effects of carbon in the atmosphere demand emissions reductions as quickly as possible. Acknowledging the urgency of the problem is not enough: effective actions are necessary.

The Urgenda Foundation is a not-for-profit organization for innovation and sustainability. It started at the Dutch Research Institute for Transitions (Drift) at the Erasmus University Rotterdam. It aims, based on science, at a fast transition towards a sustainable society, along with entrepreneurs, civil society 
organizations, local governments and companies who have understood the need for a rapid transformation. Urgenda helps front runners with scaling up and opens up and stimulates new markets. In 2008, it imported the first electric vehicles that were made in series in Norway and sold them to Amsterdam and other cities. That stimulated the cities to start a network of charging stations and in this way kickstarted the market for electric vehicles. In 2010, Urgenda organized the first collective buying initiative for solar panels and imported 50000 solar panels (PV) for thousands of citizens, which reduced the Dutch market price by 30 percent. Others followed with numerous collective buying initiatives.

Thus, Urgenda looks for innovative ways to make the necessary changes in the system. The climate case that Urgenda started in 2012 can also be seen as an innovative way of working within the legal system, to force a government and its politicians to do what their duty of care demands from them. This means to finally implement their own norms and plans, based on science, and live up to the promises that they have made year after year to reduce GHGs.

The goal of reducing GHG emissions was discussed amongst almost all countries in the world within the United Nations Framework Convention on Climate Change (UNFCCC) and its related agreements. In 2010, at the climate summit in Cancún, it was decided that so-called Annex 1 countries (the 'old' developed countries) should reduce their GHG emissions by 25-40 percent against 1990 levels by 2020 in order to keep the temperature increase below $2^{\circ} \mathrm{C}$ compared to pre-industrial times. This emission reduction range was based on broad scientific agreement. Based on that broad scientific agreement, the Netherlands in 2007 had set its own goal of 30 percent reduction by 2020 . However, there was no concrete action and, three years later, a newly elected Dutch government abandoned this target out of political convenience without any scientific justification.

It was the lack of concrete action and the lack of ambition by the Dutch government in the face of dangerous climate change that convinced Urgenda of the need to find new tools to tackle the crisis. The climate crisis can no longer be solved by consumer and business action alone. It will need the full force of government action as well, as we have waited too long to take action and time is running out. According to both science and the countries' negotiation in the context of the UNFCCC, a reduction in GHG emissions of 25 percent by 2020 was the absolute minimum necessary to stay below $2{ }^{\circ} \mathrm{C}$. And yet, according to Urgenda, such reduction was not even enough to avoid dangerous climate change, and the Netherlands would be highly unlikely to meet this target without substantial extra efforts. It was against this background that, in 2012, the Urgenda Foundation demanded greater action from the Dutch government by suing it for failing to implement effective climate policies to live up to its own acknowledged goal of 25-40 percent reduction by $2020 .^{4}$ 


\section{CO-PLAINTIFFS}

In the Netherlands, a non-governmental organization (NGO) like Urgenda is allowed to represent so-called 'public interests' in court, such as the interest in a sustainable future. Urgenda, however, did not want to run the case by itself. Climate change affects each and every person from all parts of society, so Urgenda decided to create the opportunity for normal citizens to join the case as co-plaintiffs. We also introduced a new word, not crowd funding, but crowd pleading: Urgenda invited people to help with the court case and send Urgenda any useful arguments or court case material or legal papers that could be of any help. Within a few weeks, more than 1000 Dutch people indicated that they wanted to support the case. In the end, 886 people became formal co-plaintiffs, including about ten children. Our co-plaintiffs would join us at all the court hearings and become active advocates of the case in the media, social platforms and in their own communities. Through our co-plaintiffs, we were able to explain to the broader public that our case was not 'just' an environmental case, but that our case was fundamentally about people and the future in which they would grow up.

At that time, this was the biggest climate lawsuit that had ever been filed. Because our case was a world first, many dismissed it as a publicity stunt. It clearly wasn't. We were dead serious in our demands and our conviction that our government was breaking the law by knowingly contributing to a climate catastrophe and not taking action to help avoid it. At that time, most people thought we could not win. There was little media attention, but the co-plaintiffs were very supportive right from the beginning.

\section{START: A LETTER TO THE GOVERNMENT (2012)}

The case was launched in 2012, with an event in The Hague close to the Parliament, where several well-known scientists, including James Hansen, highlighted the urgency of taking action and reducing GHG emissions. We subsequently wrote a letter to the government in which we outlined our demand that the government reduce its GHG emissions by 25-40 percent by 2020 , and, preferably, reduce them by 40 percent. We also informed the government that we intended to start litigation if it did not increase its climate ambition and act upon it. What we demanded, in essence, was that the government would reduce emissions to the level that it had recognized itself was necessary to avert dangerous climate change. For years, the Dutch government had recognized that average global temperatures should not increase by more than $2^{\circ} \mathrm{C}$ above pre-industrial levels and that, in order to do so, countries such 
as the Netherlands would need to reduce their emissions by at least $25-40$ percent by 2020 .

The response of the government to our letter was predictable yet emblematic of the attitude of so many governments around the world. The Dutch government recognized the severity of the climate crisis and the need to take more action. But it was only prepared to act if other countries acted as well: 'if others don't act, we don't act'. The Netherlands, at that time already a laggard in Europe, wrote to us: 'we do not want to be a front runner, because that is not good for our economy'. After this refusal of the government to take the necessary action, Urgenda commenced the preparation to file the lawsuit.

\section{THE URGENDA CASE FOR CLIMATE ACTION}

The central claim of Urgenda and its 886 co-plaintiffs before the District Court of The Hague was that the state had acted negligently in failing to adopt a necessary and proportionate level of ambition in its climate policy, thereby threatening the well-being of its citizens, and that this behavior was contrary to the state's duty of care towards Urgenda, the people it represents, and broader Dutch society. By acknowledging the nature, seriousness, and timing of climate change and continuing to contribute to the problem, Urgenda and its co-plaintiffs also claimed that the state was violating their rights to life, health, private life, and family under the European Convention on Human Rights (ECHR).

In essence, Urgenda claimed that delaying emissions reductions into the future would result in higher total emissions, increasing the chance of exceeding the remaining carbon budget. Relatedly, implementing emissions reductions at a later point in time is less cost effective than reducing emissions now. By kicking the can down the road, the Dutch state is only increasing the risks and the costs of climate change. Urgenda therefore requested an order that the state limit its emissions by 25-40 percent by the end of 2020 (compared to 1990 levels) because this is what science had determined as the minimum reduction for countries such as the Netherlands in order to avoid dangerous climate change, a necessity that had been frequently formally recognized by the state, so it was not invented by Urgenda or the judges. Urgenda simply demanded that the Dutch state live up to its own norms.

While the state acknowledged the severity of the climate crisis and the need to limit global temperature rises, it claimed that its current climate policies were sufficient to achieve this objective and that different reduction paths were available. In addition, the state dismissed the role of the courts in enforcing obligations in the context of climate change by arguing that the judiciary has no role to play in adjudicating 'political' disputes. Furthermore, the state argued that there is no legally binding obligation arising from national or international 
law to take measures to achieve a 25 percent emissions reduction target and, therefore, that it cannot be forced to adhere to such a target. The government shirked its responsibility by arguing that stronger ambition would have very little effect on global mitigation efforts because of the small contribution of the Netherlands to global emissions.

In summary, the dispute between the parties did not concern the need for mitigation, but rather the level at which the state needs to reduce GHG emissions, and whether the state could be forced by judges to act.

\section{DEFINING THE DUTY OF CARE AND THE 'REFLEX EFFECT'}

In its judgment of 24 June 2015, the District Court found that Urgenda, as a foundation, had standing under Dutch law.

The heart of judgment of the District Court was based in civil law/tort law. Thus, the judgment was not based directly on environmental law, public law, international law or human rights law, as many people incorrectly wrote. Furthermore, Urgenda did not fight a decision or an act of the state. Urgenda's basic claim was that the state, in not doing what was necessary to avoid dangerous climate change, breached its duty of care towards Urgenda and the citizens. The District Court concluded that there is no directly legally binding obligation on the state based on Article 21 of the Constitution, nor one based on the 'no harm' principle or the UNFCCC (climate treaty) and its protocols, nor directly based on European Union (EU) law. However, as Urgenda had submitted, the Court acknowledged that the duty of care under Dutch tort law is a so-called 'open norm' and that this norm could be 'colored' or filled in by acknowledged norms in international law. Thus, international law, including the ECHR, can be a source of interpretation of open private-law standards, like the 'standard of care of responsible conduct' to which the state must abide. These international norms and standards of what the state ought to do, have a 'reflex effect' in national law and can be used by the courts to establish and set the standard of care and proper conduct of what the state must do according to national law. This 'reflection effect' is an acknowledged rule in the Dutch legal system and is comparable to the concept of 'consistent interpretation'. This means that the Court found that decisions and standards that were developed under the UNFCCC and European Union treaties should be considered and provide guidance in determining the scope of policymaking and the state's duty of care. Similarly, the Court listed several guiding principles at play, including the equity principle, the precautionary principle, and the sustainability principle. In addition to determining the minimum degree of care, the indirect use of international and constitutional rules was also used to determine what degree of discretionary power the state is entitled to exercise. 


\section{UNLAWFUL HAZARDOUS NEGLIGENCE?}

The legal question to be answered was: is there a breach of the duty of care for taking insufficient measures to prevent dangerous climate change (unlawful hazardous negligence)? The District Court was very clear: yes.

The Court found that in order to prevent irreversible climate change, worldwide GHG emissions reductions are necessary. Citing the scientific consensus on the need to reduce emissions, the Court reiterated that industrialized nations such as the Netherlands must reduce their emissions by 25-40 percent by 2020 to prevent dangerous climate change. However, based on the state's climate policy as at 2015 , the Netherlands would only achieve a 14-17 percent reduction in emissions by 2020. Thus, the Court found that the Netherlands' reduction target was below the standard deemed necessary based on climate science and international climate policy to prevent a global increase in temperature beyond $2^{\circ} \mathrm{C}$.

The Court stated very clearly that current global emissions and the reduction targets of signatories to the UNFCCC were insufficient to realize the $2^{\circ} \mathrm{C}$ target and that the chance that dangerous climate change would occur was very high. It stated further that mitigation measures should be taken expeditiously, as 'the faster the reductions can be initiated the more chance danger will subside'. Taking into account that the state had known about this danger since at least 1992, and given the high risk of hazardous climate change, the Court held that 'the state has a serious duty of care to take measures to prevent it'. Furthermore, the Court made clear that the state plays a crucial role in, and should take a high level of care for, the statutory and instrumental framework. The Court also found that taking action would not be too 'onerous': the Dutch state can afford the measures, and immediate action is more cost-effective than postponing action. There is no cost obstacle to adhere to a stricter target of 25-40 percent (indeed, in 2010 the Netherlands had a goal of 30 percent reduction by 2020).

The Court explained that mitigation is the only effective tool and that 'the state has a duty of care to mitigate as quickly and as much as possible'.

\section{DISCRETIONARY POWER}

The Dutch government's main line of reasoning both in and outside the Court was that this was a political question and not up to the courts to decide. The judges admitted that a government has significant discretionary power, but that its discretion in deciding upon its policies is not unlimited and therefore not completely exempted from any judicial scrutiny. In other words, if there is a high risk of dangerous climate change with severe and life-threatening conse- 
quences for humans and the environment, the state has an obligation to protect them. The Court added that the only effective remedy is to reduce emissions of greenhouse gases, and that, therefore, the state has limited options: 'mitigation is vital for preventing dangerous climate change'.

The Court did not agree with the state's submissions that this case was an interference with the distribution of powers. In the Netherlands, there is not a full separation of powers, but there is a balance between state powers. The judiciary has its own task and responsibility based on the law (thus, a democratic function with democratic legitimization) that requires that the courts must provide legal protection to citizens who demand to be protected from a government that fails its responsibilities and duties - here, refusing to prevent dangerous climate change. The state did not bring forward any compelling other social interests that could demand another outcome. In words of the Court:

[T]he possibility of damages for those whose interests Urgenda represents, including current and future generations of Dutch nationals, is so great and concrete that given its duty of care, the state must make an adequate contribution, greater than its current contribution, to prevent hazardous climate change.

The Court found that the Netherlands' relatively small share of global emissions did not interfere with the country's responsibility to meet its prior commitment of a 25-40 percent reduction target by the end of 2020. The Netherlands cannot solve the climate change problem, but it must do its fair share, just like all other countries, as no country can solve the problem on its own.

All the arguments of the state failed, and Urgenda won the case on all arguments. The landmark verdict was delivered on 24 June 2015 . It was written by three judges who must have spent hundreds of hours on the case and deeply understood the urgency and the need for the judiciary to step in and fulfill its role to protect citizens against a government that is failing to act in an emergency situation.

\section{THE DUTCH STATE APPEALED}

Tens of thousands of people from all over the world asked the Dutch government 'Do Not Appeal', from famous actors to scientists, from citizens to companies, and all the co-plaintiffs. But the Dutch government still appealed the decision in September 2015. Its main argument in the press was that 'the judges were sitting on their chairs'. In reality, the government fought the judgment with every argument that it could find. It had 29 grounds of appeal.

Although Urgenda was very happy that it had won its case based on 'hazardous negligence' and breach of the duty of care in tort law, it considered that 
there was one thing in the verdict that was not correct and that it was worth filing a cross-appeal given that the state was appealing.

In its judgment, the District Court had not ruled on the question of whether the state's inaction on climate change also constituted a direct violation of the ECHR. The District Court found that Urgenda itself, being a legal body and not a human being, could not be designated as a direct or indirect victim of climate change and that therefore it could not claim a violation of human rights, specifically in relation to Articles 2 (right to life) and 8 (right to private life and family) of the ECHR. Thus, although the District Court found that these Articles could serve as a source of interpretation for the scope of the duty of care of the state under civil law/tort law, Urgenda as an NGO could not invoke these articles directly.

In contrast to the District Court, Urgenda was of the opinion that although it could not be seen as a direct victim of climate change, it could still be allowed under Dutch law to represent the interests that are protected by Articles 2 and 8 of the ECHR and that therefore Urgenda should also be allowed to directly rely on these provisions during the proceedings. It was on this question - the ability of an NGO under Dutch law to rely on the provisions of the ECHR that Urgenda filed a cross-appeal.

\section{THE HUMAN RIGHTS DIMENSION OF CLIMATE MITIGATION}

All the 29 arguments of the state were dismissed, one by one by the Court of Appeal. But our one argument in the cross-appeal was accepted! The Court of Appeal agreed with Urgenda and found that the District Court erred in concluding that Urgenda could not invoke Articles 2 and 8 under the ECHR. On 9 October 2018, the Hague Court of Appeal upheld the decision of the District Court, ordering the state to achieve a reduction of at least 25 percent by the end of 2020.

The Court stated that the state owed a duty of care under the ECHR, which is European Law, and which is of a higher order than national law. Thus, now the Urgenda case was walking on two legs that led to a duty of care to reduce the emissions by at least 25 percent, one from tort law and one from international human rights law.

The Court of Appeal, agreeing with the District Court, ruled that the requested order did not undermine the separation of powers. When the state violates its duty of care, the Court must exert its review power over the unlawful actions, while still giving the state sufficient room to decide how to comply with the order. On this point, the Court reiterated that Urgenda's claim is not intended to create legislation or to determine exactly how the state should reduce emissions. The state retains complete freedom to determine 
which measures it will implement to comply with the order. The Court held that, while a reduction of GHG emissions by 40 percent might be necessary, it is within the discretionary power of the state to determine the upper limit of required actions, but the minimum threshold of a reduction of GHG emissions by 25 percent must be met. At that point, the political discretion reaches its outer limits and it is the role of the judiciary as a co-equal branch of government, to guarantee that these limits are observed by the political branches of government.

In sum, the Court of Appeal found that the state had done too little to prevent dangerous climate change, failing to fulfill its duty of care. To remedy the situation, the Court affirmed the order to reduce emissions by at least 25 percent by the end of 2020 .

On 8 January 2019, the state moved to appeal to the Supreme Court. On 24 May 2019, the case was heard before the Supreme Court, with both parties submitting written replies the following month. The independent advice of the Advocate General and the deputy Procurator General was issued in September 2019 to the Supreme Court. These two independent advisors stated in the extremely long and outstanding advice that the decision of the lower courts should be upheld. This was exactly what the Supreme Court did on 20 December. We finally won!

\section{ASSESSING THE IMPACT OF THE URGENDA CASE IN THE NETHERLANDS AND BEYOND}

The court decision mandating the state to meet a 25 percent reduction by 2020 has transformed climate change policy in the Netherlands. Despite the decision to appeal both judgments, the state announced it would uphold its commitment to implement the order to reduce emissions. Although the government still has to close part of the gap towards the 25 percent reduction by 2020 , it has adopted a range of additional policy measures, ranging from energy efficiency measures for consumers and industry, stimulating more renewable energy production and the closure of at least one coal-fired power plant. A larger implementation plan was presented to the Dutch Parliament in April 2020, including a large reduction of the capacity of coal fired ower plants (roughly with $75 \%$ ), and the implementation of 30 measures that Urgenda had proposed in its ' 54 climate solutions plan'.

After the judgment, climate change has also dominated the agenda of the new coalition government. Both favorable decisions have allowed public officials supporting climate ambition to anchor their legislative proposals in the need to implement the court's order. Together with the Paris Agreement, the case inevitably transformed the political discourse, allowing politicians to leverage the space to push for more climate ambition in the legislative sphere 
and request periodic updates on the implementation of climate targets. In the aftermath of the judgment, the government passed legislation to phase out all coal power plants by 2030 and passed the Climate Act, which calls for a 49 percent emissions reduction by 2030 and a 95 percent reduction by 2050 . In essence, the Urgenda case has helped to build broad consensus around the fact that the Dutch state is not doing enough on climate change, creating significant momentum for action in the short term.

The Urgenda case has raised the visibility of climate change in the Netherlands, placing it as a major issue on the political and social agenda. Climate change went from being a non-issue to one of the most important issues in public discourse, with extensive coverage in national and international media. The case also helped build a stronger narrative for climate action, by framing the problem as an issue affecting current and future generations in the Netherlands. Perhaps most importantly, the case elevated the responsibility of the government in tackling climate change, particularly when the Dutch state acknowledges the problem and has committed year after year to take action. In March 2019, the country witnessed one of the greatest social mobilizations in its history, when over 40000 people marched to demand stronger action by the government.

The Urgenda case, and particularly the decision of the Supreme Court, represented what many scholars have referred to as a 'rights turn' in climate change litigation. The judgment has signaled the role of grounding legal arguments in human rights law and the increasing receptivity of courts towards these types of claims.

Climate litigation has the potential to shake the status quo by demanding real action from national governments. Lawsuits build on the national and international obligations of states to prevent and limit catastrophic climate change. They do not create new obligations; they simply ask governments to honor their existing commitments. While climate litigation by itself will not solve the problem, it is an additional strategy in a broader toolkit to demand that governments respect, promote and fulfill their human rights obligations in the context of climate change.

Since 2015, dozens of cases that were inspired by the Urgenda judgment have been filed around the world, many of which raise similar legal arguments regarding the obligation of states to prevent dangerous climate change. While each context is unique, all governments must fulfill their legal obligations as they relate to the threat of dangerous climate change. The case has pushed the boundaries of legal thinking and inspired further innovation in the field. The case has set an important precedent and has given advocates hope at a moment when many have lost faith in the political process. Ultimately, it has given people around the world a new tool with which to claim protection of their fundamental rights. 


\section{NOTES}

1. Planbureau voor de Leefomgeving, 2010. 'Correctie formulering over overstromingsrisico Nederland in IPCC rapport', accessed 26 August 2020 at https://www .pbl.nl/correctie-formulering-over-overstromingsrisico.

2. CBS (2019), 'Aandeel hernieuwbare energie naar 7.4 procent', 25 May, accessed March 2020 at https://www.cbs.nl/nl-nl/nieuws/2019/22/aandeel-hernieuwbare -energie-naar-7-4-procent.

3. Planbureau voor de Leefomgeving (2018), '2020 doesteling niet-emissiehandelssectoren ruim haalbaar', accessed March 2020 at https://themasites.pbl.nl/ balansvandeleefomgeving/jaargang-2018/themas/energie-klimaat-lucht/emissies -broeikasgassen.

4. Urgenda (n.d.), 'The Urgenda climate case against the Dutch government', accessed March 2020 at https://www.urgenda.nl/en/themas/climate-case/. 